American Journal of Environmental Sciences 7 (2): 150-160, 2011

ISSN 1553-345X

(C) 2010 Science Publications

\title{
Climate Change and its Implications to National Security
}

\author{
Mamunur Rashid, Joy Jacqueline Pereira, Rawshan Ara Begum, \\ Sarah Aziz and Mazlin Bin Mokhtar \\ Institute for Environment and Development (LESTARI), \\ University Kebangsaan Malaysia, Bangi, 43600, Selangor, Malaysia
}

\begin{abstract}
Problem statement: Climate change is increasingly one of the most serious national security threats which will have significant impacts on natural and coastal resources, ecosystem, human health and settlements, thereby affecting human wellbeing. At the same time, it is likely to influence of large scale human migration, economic and social depression over scarce natural resources and political systems necessary involve an even higher degree of uncertainty. Crucial for action is addressing climate change threats to small island states and states that are least developed, as environmental destabilization may lead to a major economic, environmental and political crisis that may not just affect these states but the world as a whole. Approach: Literatures were identified for review through a comprehensive search by using electronic and non-electronic databases. Related published literature and documents were searched in a systematic way using a range of key words relating to climate change impacts and national security. Results: The literature review indicates that climate change undermine national security dimensions by increasing environmental degradation, resources scarcity, large scale human migration as well as damage of infrastructure. The review also indicate that climate change undermine environmental dimensions by increasing sea level rise, extreme weather events, freshwater scarcity, land degradation and pollution; undermine economic dimensions by reducing access to and the quality of natural resources and human health, in addition to undermine of political dimensions with the possibility of increased environmental refugees, severe storms and failed economics. Conclusion: Reducing climate-induced threats that contributes to national security, there will need to develop an integrated approach in local and national levels and implement sustainable adaptive strategies as well as climate security.
\end{abstract}

Key words: Climate change, national security, environmental dimensions, economic dimension, political dimensions, implications

\section{INTRODUCTION}

In general, security is the condition of being protected from danger, or freedom from care, anxiety or apprehension (Barnett, 2003). It is the concern of individual or collective safety from contingency. Soroos (1997) defines security as 'the assurance people have that they will continue to enjoy those things that are most important to their survival and well-being'. Since the late 1980s and 1990s, scholars have sought to embrace a more elastic definition of national security to encompass such as safety of national territory and sovereignty, protection of human right, social and economic wellbeing, as well as political stability (Brown, 1977; Müller et al., 2007; Mathews, 1989). They also argue that it is the absence of threats or danger from environmental hazards that can maintenance of a new environment and it is the fulfillment of national interests including basic survival and protecting the health and prosperity of the nations populace. In this view, almost every nation has national security strategy and climate change has also become widespread in many national policy discussions. For instance, the United Kingdom's national security strategy (United Kingdom, 2008) in the discussion of drivers of insecurity, noted that climate change is potentially the greatest challenge to global stability and security and therefore to national security. Tackling its causes, mitigating its risks and preparing for and dealing with its consequences are critical to our future security, as well as avoiding humanitarian disaster.

The security implications of climate change are a topic of important academic research in the international scholars begins to experience the force of climate change impacts. A number of studies have been conducted in many parts of the world based on

Corresponding Author: Mamunur Rashid, Institute for Environment and Development (LESTARI), University Kebangsaan Malaysia, Bangi, 43600, Selangor, Malaysia Tel: +60166179117 
security issues related to climate change. Nonetheless, few studies argue that it poses a long-term threat, with significant implication for quality of life and greatest challenge for any certain individuals, communities, nation-states and even the globe (Scheffran and Battaglini, 2011; Penny, 2007; Ibarraran et al., 2009). At the same time, some climate-induced events tend to deteriorate or destroy physical or social infrastructure, economic and social depression over scarce natural resources, large scale human migration, as well as undermine the development and political stability (Ibarraran et al., 2009; Lioubimtseva and Henebry, 2009). The attention of such problems could derive in a global and progressive crisis that could challenge human survival in the planet, turning this phenomenon in a potential threat on human health, natural and water resources, thereby affecting human wellbeing, especially those already at risk from internal instability and economic weakness (Omann et al., 2009; Reuveny, 2007).

With an increasing focus on national security consequences of climate change, speculation about how global warming and extreme weather events affects the life support systems in the world (Scheffran and Battaglini, 2011; Parry, 2007). Rising global temperatures will likely induce environmental changes in many parts of the world. These could include reduced water availability and droughts; increased floods and storms; sea-level rise that directly and indirectly threaten human health and undermined food and water security (El-Nesr et al., 2010). A rise in air and water temperature, erratic rainfall and associated extreme weather events also affects national key economic sectors (El-Nesr et al., 2010). In addition, the impacts of projected sea-level rise could be disastrous, threaten the whole economy and exacerbate insecurity, particularly in low-lying and island states in the world. Each of these environmental changes would create significant threats on natural and coastal resources, ecosystem as well as human health and undermine the infrastructure of society and adversely affects human system (Ball, 2009).

So, climate change is a national security issue varies across the world (Podesta, 2007; Brown et al., 2007; Barnett, 2003). This literature typically suggests that climate change will aggravate existing problemssuch as poverty, social tensions, environmental degradations as well as weak political institutions that threaten state stability. Figure 1 demonstrates that the implications of climate change have potential impacts to the various sectors in a negative and positive way.

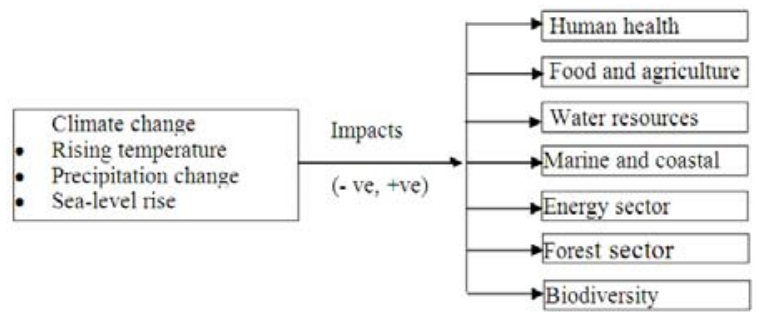

Fig. 1: Climate change impacts to the various sectors

Most impacts are expected to be negative though some sectors in some locations my benefit from the initial change in climate. This study illustrates how climate change is connected to the national security issues. Discussion also includes aspects that may undermine national security in the present and future day from the dimensions of environmental, economic and political.

\section{MATERIALS AND METHODS}

This study reviews literature from various sources such as journals, reports, proceedings and related documents on security implications due to climate change. Studies were identified through a comprehensive search by using electronic and nonelectronic databases. Several electronic databases (Science Direct, Springer Link, Blackwell, Social Science Citation Index and so on) were searched for published literature in a systematic way using a range of key words relating to national security and climate change. Internet search engines were also used to find the related published documents and reports. References cited in the literature were searched and important studies were collected in full text. Related literature and documents were also found through communicating with colleagues working in the research area. But the studies were mostly least-developed and developing countries. This review included the studies that contained data, findings and evidences based on climate change and security threats including environmental, economic and political security consequences and its widespread impacts on individuals, communities, as well as national well beings.

\section{RESULTS AND DISCUSSION}

This study is based on the evidences and findings from published literatures and documents that highlight and discuss the national security from the view of climate change, depending on the availability of literature and documents. 
Am. J. Environ. Sci., 7 (2): 150-160, 2011

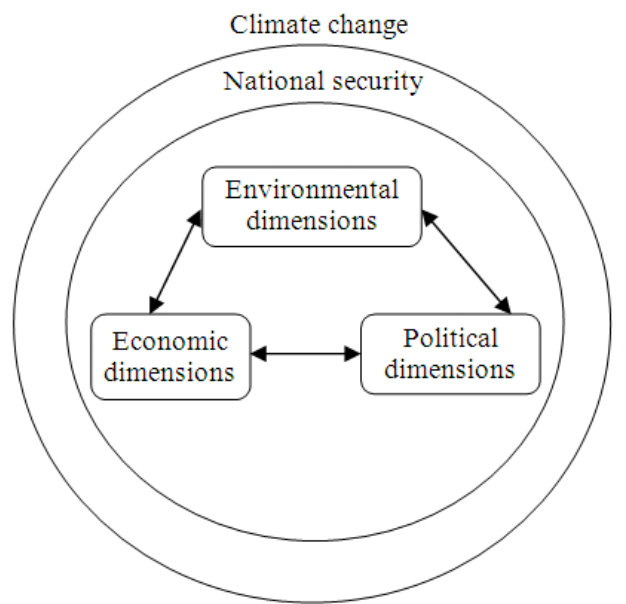

Fig. 2: Relationship between climate change and national security dimensions

Climate change and national security: The scientific evidence is now overwhelming that climate changes poses many threats and challenges to the security and prosperity that facing humanity all over the world (Barnett and Adger, 2007; Busby, 2007). While national securities have been largely the domain of governments and the military, the concept of human security is centred on the security and welfare of human beings (UNDP, 1994). The observed and projected impacts of climate change may have many direct and indirect consequences that can undermine the function of state legitimacy to provide the opportunities and services over-long time scales (Scheffran and Battaglini, 2011). In this context, some of the stress factors such as floods, storms, droughts and heat and sea level rise could lead to environmental degradation, resources depletion, largescale migration, spread the disease and rise to greater competition for the earth's resources (Penny, 2007). In addition, high population growth, inadequate freshwater supplies, strained agricultural resources, poor health services, economic decline and weak political intuitions, high incidence of poverty and social inequality and poor infrastructure also plays significant threats to the nation (UNDP, 2007; Barnett, 2011). Begum et al. (2011) emphasized that within a particular country there are different levels of vulnerability and resilience reflecting differences in location, socio-economic circumstances and level of preparedness.

National security is partly a function of state legitimacy (Barnett, 2003) where people can lead their life in peace and stability, without any visible or projected challenges, risk and threats against their welfare, the stability of political, economic, technology or ecological systems (Richard, 1983; Müller et al.,
2007). In this context, few empirical studies (Busby, 2007; Penny, 2007; Scheffran and Battaglini, 2011) have examined the effects of climate change on national security. They argue that frequency and intensity of extreme weather events, forest fire and sea-levels rise that will be the challenge in many individuals, communities as well as nation's stability, particularly in weak and fragile states with poorly performing institutions and systems of government. Significant rising sea-levels and more climatic events also damage the low-lying states and destroyed the infrastructure which may lead to a major socio-economic crisis that may not just affect these states but the world as a whole (Walker and Schulze, 2008).

The Parry (2007) suggests very few concrete links between climate change and security threats. Rising temperature, precipitation changes and extreme weather events could significant threats on national key economic sectors such as energy, industries, transport, agriculture, water and coastal resources, public health.

UNDP (2007) reported that during the flooding, affected people lost their homes and livelihoods as well as access to medical facilities, sanitation and safe drinking water. In addition, repeated and catastrophic flooding led to increased vulnerability as people not only lost their houses but also lost their harvest and means of livelihood (Reuveny, 2007). Sea-level rise, intensive storms and heavy precipitation would increase the risk of natural disasters in coastal zones, in particular in South Asia, China and the USA (Scheffran and Battaglini, 2011). Most affected would be the region's ecosystems and biodiversity, water and agriculture, forestry, fisheries and livestock resources and poses a threat to social and political stability. Figure 2 shows climate change threats to the national security that could be a combined assault onto the different dimensions of environmental, economic and political security. These national security dimensions includes such as economic growth and development, structure of economic process, welfare of citizens, variability of climatic conditions, preservation of natural resources, political stability and so on (Scheffran and Battaglini, 2011).

Studies suggest that climate change can be expected to contribute to resources scarcity through disruption of production cycles, extreme weather patterns, desertification or reduction of water resources (Penny, 2007; Ball, 2009). A drop in agricultural productivity and decreased availability and quality of fresh water due to flooding and droughts and disrupted access to strategic minerals due to ice and storms has the potential to cause civil unrest and lead to significant economic losses particularly in the developing countries (Schwartz and Randall, 2003). 
Am. J. Environ. Sci., 7 (2): 150-160, 2011

Table 1: Factors contributing risks and threats to the national security dimensions

\begin{tabular}{ll}
\hline Climate-induced factors & Process which clime-induced factors could affect/exacerbate \\
\hline Sea level rise & $\begin{array}{l}\text { Rising sea-levels are likely to causes potential loss of land, damage of crops yield, coastal erosion and } \\
\text { infrastructure, affect coral reefs, mangroves as well as sea areas. Millions of people are forced to } \\
\text { migrate due to undermined resources as well as infrastructure (Aung et al., 2009; Piguet, 2008; }\end{array}$ \\
& $\begin{array}{l}\text { Nicholls et al., 2007). } \\
\text { A change in rainfall pattern and rising temperature is significantly affecting the sustainable living and }\end{array}$ \\
Variability of climatic conditions & main socio-economic components. Some of the climate driven outcomes are large scale and chronic \\
e.g., Temperature, Rainfall. & (such as declining agricultural productivity, water and energy resources). Rainfall pattern is also \\
increase the vector and water bone-disease while heat stress increases respiratory diseases & (Lioubimtseva and Henebry, 2009; Penny, 2007; Warmer, 2010). \\
Extreme weather conditions e.g., Flood, & The impacts of extreme climate events which enhance vulnerability, disruption to the livelihood by \\
drought, wind storms, forest fire. & $\begin{array}{l}\text { damaging crops at particular development stages and generation of individuals or groups, increase } \\
\text { social stress. These include physical changes, such as damage infrastructures, collapse of economic } \\
\text { growth and development and also risk of major societal changes, such as large scale migrations and } \\
\text { political instability (Ibarraran et al., 2009; Boutraa, 2010). }\end{array}$ \\
\hline
\end{tabular}

Table 1 depicted some key factors by which climate change may undermine ecosystems, water and food resources, human health and the settlements, which may also induce state failure. Such phenomena will affect the parameters of security dimensions and sometimes important to increases the risk that people will join armed groups.

Atoll countries are the most physically vulnerable to sea-level rise of all small island states, because of their high ratio of coastline to land area, relatively high population densities and low level of available resources for adaptive measures (Aung et al., 2009; Barnett and Adger, 2003). For instance, Tuvalu, Kiribati and Maldives are faced with coral bleaching, sea-level rise, salt water intrusion, water scarcity and increasingly severe weather events-all with very real, financial and social costs for vulnerable economics. It is not a concern for atoll countries alone, although small islands states and states have significant risks to the livelihoods, culture, health as well as many social and ecological contexts (Barnett, 2011). For example, Bangladesh, Vietnam and India are situated near major rivers, deltas and estuaries are increasingly prone to flooding resulting risk to the sustainability of those communities (Alam and Ahmed, 2010). In Bangladesh, about $80 \%$ of the land is the floodplains and one third is under tidal influence (Karim and Mimura, 2008), drought, desertification and cyclonic events are the major drivers that affect the agricultural products as well as human beings (Shahid and Behrawan, 2008).

From the above evidence, it seems that it is a national security issue that may raise despair and violence to the different dimensions of national security. However, it is important to survey the literature how climate change may affect or undermine the different dimensions of national security over the few decades. Towards this, the following reviews describes how climate change may undermine through the dimensions of environmental, economic, as well as political aspects of national security.

Environmental dimensions: Evidence shows that global climate change is expected to bring about a number of significant changes to the environment which will have profound impacts on ecosystem, natural resources and coastal resources, thereby affecting human wellbeing. The decreasing availability of physical, environmental and land resources could create a condition of simply scarcity and deprivation in the area which influence large scale human migration as well as affect country's development progress (Lioubimtseva and Henebry, 2009; Warmer et al., 2010). However, such impacts are likely to increase world and country-scale inequity, within the present generation and between present and future generations, particularly in developing countries (Parry, 2007).

The environment is the planetary support system on which all other human enterprises depend based on providing sources of food and water, pleasant surroundings and sceneries and transportation lines (Hojat, et al., 2010). There are several process and trends that have the potential to threaten stability and destroy the fragile equilibrium on earth. Among the process, environmental changes are increasing vulnerable on many individuals, groups, community, as well as national interests (Warmer et al., 2010; Begum et al., 2009). Some recent studies indicate that the major environmental threats are desertification and deforestation, global warming and ozone depletion, rising sea-levels and extreme weather events, air and water pollution, population growth and natural disasters (Barnes et al., 2009; Scheffran and Battaglini, 2011). In this context, the changing environment not only affect the life of human beings but may also generate larger societal effects, either by undermining the infrastructure of society or inducing responses and adversely affecting social systems. In fact, the 
Am. J. Environ. Sci., 7 (2): 150-160, 2011

associated socio-economic and political stress can erode the functioning of communities, the effectiveness of institutions and the stability of societal structures.

Studies suggest that, climate change is a unique challenge to the human wellbeing's due to influence the resources scarcity, especially water, food and energy (Warmer et al., 2010; Schwartz and Randall, 2003) and also stress in existing institutional systems of public health in many countries in the world (Ball, 2009). In addition, in a report for the Pentagon, Schwartz and Randall (2003) argue that as abrupt climate change would result in a further deficit and deaths due to starvation and fought over food, water and energy. Based on IPCC (Parry, 2007) report, (Raleign and Urdal, 2007) identified three major processes that are likely to have security implications: degradation of cropland, increasing freshwater scarcity and population displacement. We argue four physical developments processes associated with climate change be clear as potential harmful to environmental dimensions such as land degradation and change in agricultural productivity; increase in frequency and intensity of natural disasters; freshwater scarcity; as well as rising sea levels and migration. First, climate change is likely to influence the food-producing capacity and land capability in many areas where some areas are likely to benefit are some are losses. Most of the influences are negative especially in tropical and sub-tropical areas in the world (Raleign and Urdal, 2007). For example, in 2007, the world food stores declined by $11 \%$ as well as food price index rose by more than $40 \%$ (Rosenthal, 2007). The current chairman of the IPCC, Pachauri projected that about $50 \%$ of agricultural yield will be reduced by 2020 in some African countries and crop revenues could fall by $90 \%$ by 2100 in Africa due to severe drought. Secondly, climate change likely to increase in frequency and intensity of natural disasters. Interpreting data from (CRED) in 1900-2011, Africa had the largest number of droughts (269), the largest number of floods (753) and wind storms (955) are occurred in Asia. Such extreme weather events could have severe socioeconomic and political instability within countries where governance systems are in transition, levels of inequality are high. Third, the temporal and spatial availability of water is expected to be highly sensitive to projected climate change. It also leads to the degradation of water quality and fresh water scarcity and it is a useful measure of human threats (Barnett, 2011). According to the UNDP (2007), more than one billion people are currently without access to clean water and about a quarter of the world's population lives in water-stressed areas. In addition, IPCC projected that about 75-250 million people will be exposed to an increase of water stress by 2020 due to climate change.

Finally, sea-level rising and increased risks of flooding could contribute to destabilizing unregulated population movements that can raise risk of resources and human health, violent particularly in the less developed countries with limited capabilities ( Aung, 2009; Nicholls et al., 2007). People will force to migrate, potentially leading to higher pressures on resources in areas of destination and subsequently to resources competition (Warner, 2010). To illustrate the danger, Bangladesh is experiencing sea-level rise substantial security risks where 45 centimeters rise in sea-level could result in the inundation of $10.9 \%$ of territory, displacing approximately 5.5 million people to relocate (Parry, 2007).

A number of studies suggest that climate change can be expected to contribute to resource scarcity, through disruption of production cycles, extreme weather pattern, desertification or reduction of water and resources which lead political instability and then state failure (Nordas and Gleditsch, 2007). For instance, climate change has already been a contributing factor in current conflicts in Darfur due to declining agricultural production, undermined food security and so on (Barnes et al., 2009). A report from HDR (2000), about 1.1 billion people in the world lack access to drinkable water, including about $46 \%$ population in Sub-Saharan Africa, 32\% in East Asia, 29\% in Southeast Asia and the Pacific and 22\% in Latin America, $18 \%$ South Asia and $17 \%$ the Arab States which shown in the Fig. 3. A larger increase in potable water stress represents is one of the greatest concerns of the human wellbeing (Boutraa, 2010), indeed as a single greatest challenge to the sub-Saharan Africa, Asia and other countries (Lioubimtseva and Henebry, 2009; Barnes et al., 2009). The highest threats from climate change are predicted to be in the agricultural and water sectors in sub-Saharan Africa because the region already endures high heat and low precipitation which turn into economic crisis as well as pressure of political stability (Barnes et al., 2009).

Economic dimensions: Over the past two decades, climate change has been presented as a global security issue that selectively undermines human dimensions of some regions and groups experiencing significant negative effects, such as loss of life and property, loss of agricultural productivity, increased water stress, economic damage, loss of infrastructure and so on (Brown et al., 2007). 
Am. J. Environ. Sci., 7 (2): 150-160, 2011

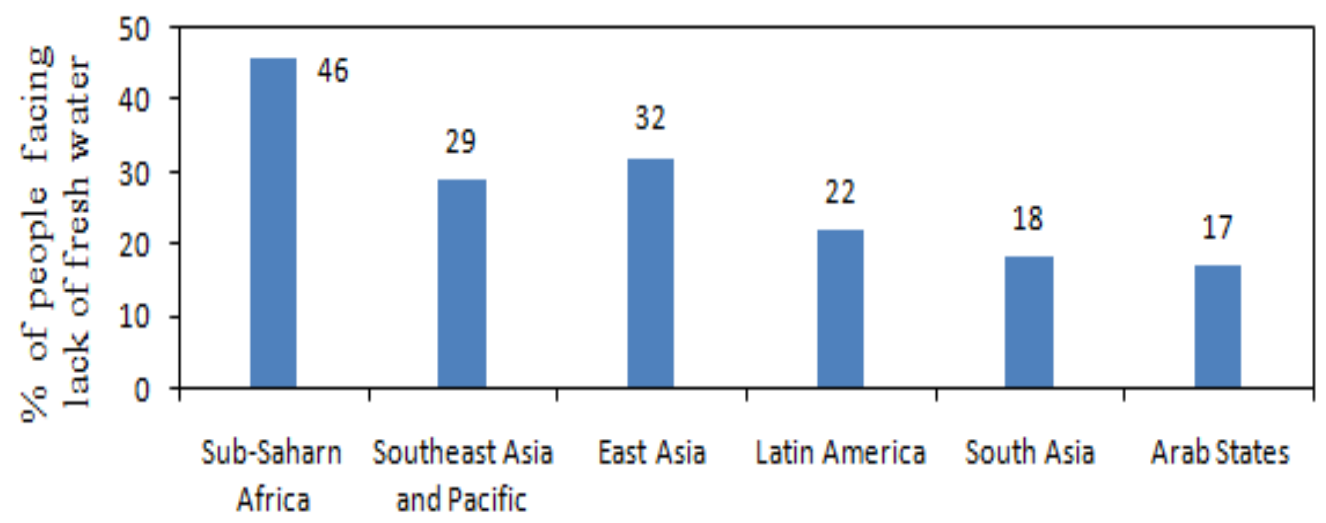

Fig. 3: Water scarcity in different region of the world (Adopted from, HDR, 2000)

Most of the socio-economic development activities are dependent and sensitive to climatic condition (Fischer et al., 2005). Rising temperature and precipitation change has been an enduring challenge in many parts of the world that may amplify existing socio-economic problems, widening the gap between rich and poor countries (Parry, 2007; Kabubo-Mariara and Karanja, 2007).

The economics of fragile states are often based on subsistence agriculture, upon which climate change will have disproportionate impact. At the same time, it will also contribute to regional water scarcity which will impede crop production, with subsequent threats to the food security, animal husbandry, while human consumption and agriculture may compete locally for access with industrial facilities (Scheffran and Battaglini, 2011; Amiri and Eslamian, 2010). Drought is an increasingly common feature in many of the world's arid and semi-arid climate zones. The world's dry-lands cover over $40 \%$ of the global terrestrial area and house more than 2 billion inhabitants (Amiri and Eslamian, 2010). For example, northern China is experiencing severe drought and consumption-related water shortages, leading the Chinese government to commission a US\$ 59 billion project to pipe water from the wet south to dry northern china (Podesta and Ogden, 2007). It is not only the long-term change in mean conditions, but also the possibility of increasingly variable; frequency and intensity of extreme events which may render welfare and livelihoods less secure (Barnett, 2011).

The way climate change and variability can and does undermine economic growth varies across the world because of worst case scenario of extreme weather events (Hoon Oh and Reuveny, 2009). They also argue that climate change and variability influence the probability of natural hazards by enhancing the frequency and intensity of extreme weather events (Ibarraran et al., 2009). They discuss that most of the climate-induced events can reduce the adaptive capacity of affected localities by damaging important infrastructure. For example, 26th December in 2004, Tsunami destroyed in 13 Asian and African countries. The monstrous waves killed more than 0.2 million people, displacing about 2 million people and resulted damage more than $\$ 6$ billion in 13 countries (Kathiresan and Rajendran, 2005). Among this affected countries, Indonesia, Thailand, Sri Lanka are worst affected. In Indonesia, this wave killed 164,897 people, causing damage $\$ 4.45$ billion and displacing about 412,438 people (UNEP, 2005). Others examples of devastating threats hitting the US, include Hurricane Katrina New (Orleans, Louisiana and Mississippi, 2005), Hurricane Rita (Houston and Texas, 2005). Elsewhere, long drought often strike Sub-Saharan Africa as well as Darfur in Sudan, powerful storms cyclone Sidor strike in Bangladesh and in latest earthquake strike in Haiti which shown in the Table 2.

So, climate-induced events can reduce adaptive capacity of affected individuals, communities and regions by damaging important infrastructure, as well as economic development. The Christian Aid charity has warned that 184 million people could die and at least one billion people will be forced from home in Africa as a result of climate change before the end of the 21st Century which intensify global migration crisis (Christian Aid, 2006; 2007). In the first instance, increasing climate variability and extreme weather events that will enhance migration as soil are degraded, water supplies are contaminated and depleted, housing, livestock and infrastructure are destroys, insurance costs rise and lives are lost. However, the arrival of the environmental migrants will be the burden of economic and as well as resource in the receiving area. 
Am. J. Environ. Sci., 7 (2): 150-160, 2011

Table 2: A worst-case scenario of extreme weather events and natural hazards since 1998

\begin{tabular}{|c|c|c|c|c|c|c|}
\hline Area struck & $\begin{array}{l}\text { Extreme } \\
\text { events }\end{array}$ & $\begin{array}{l}\text { Lost of } \\
\text { people }\end{array}$ & $\begin{array}{l}\text { Migration } \\
\text { peoples }\end{array}$ & $\begin{array}{l}\text { Economic } \\
\text { damage }\end{array}$ & $\begin{array}{l}\text { Infrastructure } \\
\text { and crops losses }\end{array}$ & References \\
\hline Indonesia, 26th December, 2004 & Tsunami & 164,897 & 412,438 & $\$ 4.45$ billion & 175,000 houses & (UNEP, 2005) \\
\hline Darfur in Sudan, 2003-2005 & Severe drought & 200,000 & 2.5 million & \$400 million & $20 \%$ crops & (Singh, 2007; Apsel, 2009) \\
\hline $\begin{array}{l}\text { New Orleans, Louisiana and } \\
\text { Mississippi, America, } 2005\end{array}$ & Hurricane Katrina & 18,00 & 1 million & $\$ 180$ billion & $80 \%$ houses & (Romilly, 2007; Reuveny, 2008) \\
\hline Bangladesh, November 15, 2007 & Cyclone Sidr & 3,406 & 887,000 & $\$ 1.7$ billion & 1 million house & (BMF, 2008; Paul, 2009) \\
\hline Haiti, January 12, 2010 & Earthquake & 316,000 & 1 million & $\$ 7.2$ billion & $75 \%$ destroyed & (IDB, 2010; Farfel et al., 2011) \\
\hline
\end{tabular}

Nicholls et al. (2007) addressed that significant global sea-level rise is very likely to affect ecosystem of lowlying areas and induce large scale migration in the longer-term. Several low-lying island states can be especially vulnerable because of multiple stresses including sea-level rise, less adaptive capacities and more dependent on climate sensitive resources such as local water and food supplies (Parry, 2007). Particularly, the small island states such as Tuvalu, the Kiribati and the Marshall Islands in the South Pacific are facing total inundation, their populations will need to evacuate to neighboring countries such as Australia and New Zealand (Aung et al., 2009; Barnett and Adger, 2003). For example, the World Bank (2001) estimates that by 2050 damages from climate change could cost Tarawa atoll in Kiribati US\$8-16 million or $17-34 \%$ of current GDP. Furthermore, the World Bank estimates the losses due to climate change in Kiribati to be in the order of $17-34 \%$ of current GDB by 2050 . Others examples of devastating floods (associated with tropical cyclones) hitting the Mozambique in 2000 resulted in a reduction in that country's growth rate from 8-2.1\% (Washington et al., 2006). These examples of this countries, strongly suggest that the risks of climate change on economic growth are severe as well as change in environmental systems. Current understanding suggests that at high levels of warming, the risks of major, irreversible changes to the climate, ecosystems and society are very real indeed. These include physical changes, such as a collapse of economic growth and development and also risk of major societal changes, such as migrations and political instability.

Political dimensions: The Third Assessment Report (TAR) of the Intergovernmental Panel on Climate Change (IPCC, 2001) firmly established climate change as a political issue on the global agenda. The Fourth Assessment Report of IPCC (Parry, 2007) predicts that climate change will manifest in dramatic ways such as extreme weather events and sea level rise. Such effects may induce resources scarcity, large scale human migration, environmental, with significant implications for almost all dimensions of human security, in addition to political and state security (Lioubimtseva and Henebry, 2009). UNDP (2007) reported that political instability is linked between environmental change and violent conflict. There is substantial empirical evidence for a connection between political instability and climate-induced migrants (Warner, 2010). Migration can also exacerbate environmental and economic problems in receiving areas. In addition, high population pressure limited migration opportunities led to communal tension within the country as well as between the nations. Other factors also enhance political instability such as poverty and inequalities between groups, lack of foreign policy, low level of democracy, incapable bureaucracy, the availability of weapons, ethnic tensions, state legitimacy, interstate and or intrastate militarized conflict as well as civil disorder (Hoon Oh and Reuveny, 2009).

A sensitive understanding of the way that climate changes are likely influence of large- scale migration. A worst-case scenario of climate change and sea-level rise may also responding to crop failure, affect the redistribution capacity of governments programs, including health, education and security that could aggravate social tensions and place pressures on vulnerable economics and turn in to political instability (Nicholls et al., 2007). In addition, they also explain that when people no longer have access to the water, food, or physical security needed for survival, they may be forced to move within country or between countries to access more secure food, water supplies and fertile land. For instance, with climate change, human insecurity and the fight for survival are likely to increase in Bangladesh, Darfur in Sudan, challenging internal social and political stability and undermining the young democratic institutions. Moreover, if government is unable to provide basic services, there is likely to be social unrest resulting in political instability. For example, climate-driven droughts and desertification has already been contributing factor in current conflicts due to resources scarcity in Darfur (Barnes et al., 2009; Apsel, 2009). The delicate balance has been upset by crop failure and widespread food insecurity, which forced increased migration of nomadic groups from neighboring states into the more fertile areas. 
Despite the ambiguity of past political instability research, there is a widespread agreement that climate change is undermining political stability in many ways. Studies suggests that some specific factors related to climate change are leading political instability such as environmental and resources degradation, large scale migration, poverty and inequalities between groups, institutional resilience and vulnerable economic, socioeconomic conditions and ethnic tensions (Reuveny, 2007; Hoon Oh and Reuveny, 2009). To illustrate the threats, climate change is expected to lead over diminishing natural and economic resources through increasing temperature, precipitation anomalies and extreme weather events. In addition, sea-level rise and increased risk of flooding is also likely to induce large scale migration where high population pressure and limited migration opportunities led to increased mistrust, inter-communal tension, within the country and between the countries.

Barnett (2003) and Scheffran and Battaglini (2011) found that climate change; human migration and political instability have been inextricably linked. They also noted that arrival of environmental migrants can burden the economic and pressures of resources are expected to arise in the receiving area. The excess demand for resources may also generate lateral pressure, expansion of economic and political activities beyond the regions' or state's borders in order to acquire resources, which increases the risk of conflict among people as well as political instability. Therefore, to avoid climate-induced migration and the subsequent risk of threats, ultimately reducing the amount of greenhouse emissions, including governmental social support, public private relationship, good governance and institutional system, intellectual property right as well as enhancing adaptive capacity is essential. Much more cross-scale research and political commitment is required to gain greater understanding the ways of climate insecurity which is the challenge for security.

Way forward for a climate security discourse: Studies of the impacts of climate change talk mostly about the future but should learn from the past. It is a security issue risks making it global common problem. The most potential devastating impacts of climate change arise from a combination of multiple stresses which include ecosystem degradation, failed governance systems and economic decline (Barnett and Adger, 2007; Nordas and Gleditsch, 2007). There are several approaches to address potential climate change impacts on nation. The most common approach to dealing with problems is to focus exclusively on reducing human contribution to climate change, which is mitigating greenhouse gases. But we argue that there is a locus of analysis that is important for understanding climate security and which is equally under-researched.

Understanding in a way, that climate security will likely become a leading concept guiding future climaterelated policies. Climate security is the protection of human civilization from the danger and loss that can be caused by climate change. So, this is an important discourse to reduce greenhouse gas emissions. We argue some complementary process to enhance climate security:

- Climate change should be given a higher political priority in each country. The way of measures and policies, economic and societal growth in a lowcarbon nature will promote transformation in relevant technologies social infrastructure, as well as lifestyles through reduced greenhouse gas emissions

- Cooperative efforts should be taken by local, national and regional as well as global dialogues on climate change issues that make decisions and implement policies to reduce greenhouse gas emissions as well as promoted environment. Efforts are also needed to promote international cooperation efforts which will strengthen the international regime under the UNFCCC, as well as assist other countries that share the concept

- Functional programs should be developed to build in intellectual capacity, awareness and emergency preparedness as well as long term measures to deal with weather-related disasters, ecological degradation and other related problem

- International pressures can be expected to grow for mandatory emissions reductions to be placed on the high greenhouse gas emitting nations that are causing the threat. Nevertheless, in light of the fact that military actions would result in increase greenhouse gas emissions, such enforcement measures would likely take the form of nonmilitary means such as economic sanctions

- There is need a tighter coupling of the climate change models and the conflict models for the physical effects of climate change, incorporating geographic variation, rates of change and adaptive measures, will facilitate the scientific interface

To cope with the multiple regional stresses in the context of increasing stresses caused by climate change, land use, political and socio-economic changes of the past decades, every nation will need to develop and implement sustainable adaptive strategies as well as climate security. In dealing with the threats of climate 
Am. J. Environ. Sci., 7 (2): 150-160, 2011

change, some adaptation strategies should be focus attention at the local level and also mitigation strategies should be given priority for protecting environment. Nevertheless, climate security is inevitable for the sustainable livelihood and sustainable living.

\section{CONCLUSION}

This study argues that climate change presents a very serious challenge to the security and prosperity for individuals, community as well as nations especially in the atoll countries and low-lying island states. While it is true that climate change likely to undermine the capacity of nations to provide the opportunities and services that people to sustain their livelihoods. In certain circumstances, it has so many potential consequences for the physical environment which may have significant impacts on economic, environment as well as political that are largely uncertain and yet catastrophic.

It is clear that climate change is a national security issue in the present and future day, through its potential negative effects on environment. In fragile states, some nation-states are facing various stresses coincide at multiple temporal and spatial scales: noticeable temperature increases, change in rainfall patterns, changes in livestock and agricultural crops, water stress, population growth, rapid institutional changes, increase of economic inequality and large scale migration. Such changes have dramatic consequences for livelihood, settlements patterns, resources pressures, potentially increasing the risk of social instability as well as political. Increasingly, it is now argued that climate change is likely to increase world and countryscale inequity, within the present generation and between present and future generations, particularly in developing countries. It has concrete links between climate change and national security including economic, social, environmental as well as political security dimensions concern. Based on these observations, we suggest that there is need a political will or commitment to reduce greenhouse gas concentration and ensure national security. We also suggest that there is a need cross-scale research for adaptive responses that would prepare for inevitable climate driven events such as mass migration, disease and food and water shortages to enhance understanding of the potential impacts of climate change on nations. It also requires understanding the ways of climate insecurity which is the challenge for security. To cope with the multiple regional stresses in the context of increasing stresses caused by climate change, every nation will need to develop an integrated approach in national and regional levels and implement sustainable adaptive strategies as well as climate security.

\section{ACKNOWLEDGEMENT}

The researchers are greatly acknowledged to the research grant Fundamental Research Grant Scheme (FRGS) in Malaysia (Ref. No. UKM-SEADPRI-07FRGS-0026-2010). Thoughtful comments from the anonymous reviewers and the journal editors are also sincerely appreciated.

\section{REFERENCES}

Aid, C., 2006. The Climate of Poverty: Facts, fears and hope. 1st Edn., Christian Aid, London, ISBN: 090437968X, pp: 44.

Aid, C., 2007. Human tide: The Real Migration Crisis. Christian Aid, London. http://www.christianaid.org.uk/Images/humantide.pdf

Alam, M.J.B. and F. Ahmed, 2010. Modeling Climate Change: Perspective and Applications in the Context of Bangladesh. 1st Edn., Springer, USA., ISBN: 9048131081, pp: 373.

Aung, T., A. Singh and U. Pasad, 2009. Sea level threat in Tuvalu. Am. J. Applied Sci., 6: 1169-1174. DOI: 10.3844/ajassp.2009.1169.1174

Amiri, M. J. and S. S. Eslamian, 2010. Investigation of climate change in Iran. J. Environ. Tech., 3: 208-216. DOI: 10.3923/jest.2010.208.216

Apsel, J., 2009. The complexity of destruction in Darfur: Historical processes and regional dynamics. Hum. Rights Rev., 10: 239-259. DOI: 10.1007/s12142-008-0099-6

Barnett, J., 2003. Security and climate change. Global Environ. Change, 13: 7-17. DOI: 10.1016/S09593780(02)00080-8

Brown, L.R., 1977. Redefining National Security. 1st Edn., World Watch Institute, Washington, ISBN: 0916468135, pp: 46.

Ball, R., 2009. Climate change and sustainable futures. Syst. Prac. Act. Res., 22: 139-148. DOI: 10.1007/s11213-009-9119-y

Brown, O., A. Hammill and R. Mcleman, 2007. Climate Change as the new security threat: implications for Africa. In. Affa., 83: 1141-1154. DOI: 10.1111/j.1468-2346.2007.00678.x

Barnett, J. and N. Adger, 2007. Climate change, human security and violent conflict. Poli. Geog., 26: 639-655. DOI: 10.1016/j.polgeo.2007.03.003

Busby, J. W., 2007. Climate Change and National Security: An Agenda for Action. 1st Edn., Council on Foreign Relations, New York, ISBN-10: 0876094132, pp: 32. 
Barnett, J., 2011. Dangerous climate change in the Pacific Islands: Food production and food security. Reg. Environ. Change, 11: 229-237. DOI: 10.1007 /s10113-010-0160-2

Begum, R.A., C. Siwar, R.D.Z.R.Z. Abidin and J.J. Pereira, 2011. Vulnerability of climate change and hardcore poverty in Malaysia. J. Environ. Sci. Tech., 4: 112-117. DOI: 10.3923/jest.2011.112.117

Boutraa, T., 2010. Improvement of water use efficiency in irrigated agriculture: A review. J. Agron., 1: 1-8. DOI: $10.3923 /$ ja.2010.1.8

Barnett, J. and W.N. Adger, 2003. Climate dangers and atoll countries. Clim. Change, 61: 321-337. DOI: 10.1023/B:CLIM.0000004559.08755.88

Begum, R.A., J.J. Pereira, A H. Jaafar and A. Q. AlAmin, 2009. An empirical assessment of ecological footprint calculations for Malaysia. Res. Con. and Recy., 53: 582-587. DOI: 10.1016/j. resconrec.2009.04.009

Barnes, B., H. Cao, T. Drab and J. Pearson, 2009. Design of sustainable relief housing in Ethiopia: An implementation of cradle to cradle design in earthbag construction. Am. J. Environ. Sci., 5: 137144. DOI: 10.3844/ajessp.2009.137.144

Bangladesh Ministry of Finance, 2008. Cyclone Sidr in Bangladesh: Damage, Loss and Needs Assessment for Disaster Recovery and Reconstruction, a Report from Ministry of Finance. Bangladesh, pp: 18. http://www.recoveryplatform.org/assets/publicatio n/9\%20sept/Bangladesh_cyclone_allthemes.pdf

Cavallo, E.A., A. Powell and O. Becerra, 2010. Estimating the Direct Economic Damage of the Earthquake in Haiti. Inter-American Development Bank. http://papers.ssrn.com/sol3/papers.cfm?abstract_id $=1817279$

El-Nesr, M.N., M.M. Abu-Zreig and A.A. Alazba, 2010. Temperature trends and distribution in the Arabian Peninsula. Am. J. Environ. Sci., 6: 191203. DOI: 10.3844/ajessp.2010.191.203

Fischer, G.M., M. Shah, F.N. Tubiello and H.V. Velhuizen, 2005. Socio-economic and climate change impact on agriculture: An integrated assessment, 1990-2080. Phil. Trans. Royal Soc. London, 360: 2067-2083. DOI: 10.1098/rstb.2005.1744

Farfel, A., A. Assa, I. Amir, T. Bader and C. Bartall et al., 2011. Haiti earthquake 2010: A field hospital pediatric perspective. Eur. J. Pedi., 170: 519-525. DOI: $10.1007 / \mathrm{s} 00431-011-1423-8$

Hoon, O.C. and R. Reuveny, 2010. Climatic natural disasters, political risk and international trade. G. Environ. Change, 20: 243-254. DOI: 10.1016/j.gloenvcha.2009.11.005
Hojat, A. H. M., K. A. Rahim and L. Chin, 2010. Firm's environmental performance: A review of their determinants. Am. J. Econ. Bus. Admin., 2: 330-338. DOI: 10.3844/ajebasp.2010.330.338

Ibarraran, M.E., M. Ruth, S. Ahmad and M. London, 2009. Climate change and disasters: Microeconomic performance and distributional impacts. Environ. Dev. Sustain, 11: 549-569. DOI: 10.1007/s10668-007-9129-9

IPCC, 2001. Climate change 2001: Synthesis report. 1st Edn., Cambridge University Press, USA., ISBN10: 0521015073 , pp: 397.

Kabubo-Mariara, J. and F. Karanja, 2007. The economic impact of climate change on Kenyan crop agriculture: A Ricardian approach. G. Plan. Change, 57: 319-330. DOI: 10.1016/j.gloplacha.2007.01.002

Kathiresan, K. and N. Rajendran, 2005. Coastal mangrove forests mitigated tsunami. Es. Co. Shelf Sci., 65: 601-606. DOI: 10.1016 /j.ecss.2005.06.022

Karim, M.F. and N. Mimura, 2008. Impacts of climate change and sea-level rise on cyclonic storm surge floods in Bangladesh. G. Environ. Change, 18: 490-500. DOI: 10.1016/j.gloenvcha.2008.05.002

Lioubimtseva, E. and G .M. Henebry, 2009. Review of climate and environmental change in arid central Asia: Impacts, vulnerability and adaptations. J. Arid Environ., 73: 963-977. DOI:10.1016/J.JARIDENV.2009.04.022

Lama, M.P., 2001. Human Development Report (HDR). 1st Edn., Berghahn Books Delhi, ISBN: 8187358041, pp: 111.

Müller, F., K.B. Jones, K. Krauze, B.L. Li and S. Victorov, 2007. Contributions of landscape sciences to the development of environmental security. Landscape Sci. Assess. Environ. Sec., 1: 1-17. DOI: 10.1007/978-1-4020-6594-1_1

Mathews, J.T., 1989. Redefining Security. Foreign Affa., 68: 162-177.

Nicholls, R. J., P. P. Wong, V. Burkett, J. Codignotto and J. Hay et al., 2007. Coastal Systems and LowLying Areas. In: IPCC WGII Fourth Assessment Report, Nicholls, R.J., P.P. Wong, V. Burkett, J. Codignotto and J. Hay et al. (Eds.). IPCC, Geneva.

Nordas, R. and N.P. Gleditsch, 2007. Climate change and conflict. J. Po. Geo., 26: 627-638. DOI: 10.1016 /j.polgeo.2007.06.003

Omann, I., A. Stocker and J. Jager, 2009. Climate change as a threat to biodiversity: An application of the DPSIR approach. Ecol. Econ., 69: 24-31. DOI: 10.1016/J.ECOLECON.2009.01.003 
Penny, C.K., 2007. Greening the security council: Climate changes as an emerging threat to international peace and security. Int. Environ. Agree.: Politics, Law Econ., 7: 35-71. DOI 10.1007/s10784-006-9029-8

Parry, M.L., 2007. Climate Change 2007: Impacts, Adaptation and Vulnerability. In: Contribution of Working Group II to the Fourth Assessment Report of the Intergovernmental Panel on Climate Change, Parry, M.L. (Ed.). Cambridge University Press, Cambridge, pp: 976. ISBN: 0521880106

Podesta, J. and P. Ogden, 2007. The security implications of climate change. Wash. Quar., 31: 115-138.

Piguet, E., 2008. Climate change and forced migration. New Issues in Refugee Research-UNHCR working pp: 153. www.bvsde.paho.org/bvsacd/cd68/new issue153. pdf

Paul, B.K., 2009. Why relatively fewer people died? The case of Bangladesh's Cyclone Sidr. Natural Hazards, 50: 289-304. DOI: 10.1007/s110690089340-5

Reuveny, R., 2007. Climate change-induced migration and violent conflict. J. Politcal Geogra., 26: 656673. DOI: 10.1016/j.polgeo.2007.05.001

Richard, H.U., 1983. Redefining security. Int. Sec., 8: 129-153.

Raleign, C. and H. Urdal, 2007. Climate change, environmental degradation and armed conflict. Po. Geo., 26: 674-694.

DOI:10.1016/J.POLGEO.2007.06.005

Romilly, P., 2007. Business and climate change risk: A regional time series analysis. J. Int. Bus. Stud., 38: 474-480. DOI: 10.1057/palgrave.jibs.8400266

Reuveny, R., 2008. Ecomigration and violent conflict: case studies and public policy implications. Hum. Ecol., 36: 1-13. DOI: 10.1007/s10745-007-9142-5

Scheffran, J. and A. Battaglini, 2011. Climate and conflicts: The security risks of global warming. Reg. Environ. Change, 11: 27-239. DOI: 10.1007/s10113-010-0175-8

Singh, A., 2007. Woman, conflict and Darfur: A case study critical concepts in international security. J. Mi. Stra. Stud., 9: 1-26.
Soroos, M., 1997. The Endangered Atmosphere: Preserving a Global Commons. 1st Edn., University of South Carolina Press, Columbia, ISBN-10: 1570031606, pp: 339.

Schwartz, P. and D. Randall, 2003. An Abrupt Climate Change Scenario and its Implications for United States National Security. 1st Edn., DIANE Publishing, Washington, DC., ISBN-10: 142898268X, pp: 1-22.

Shahid, S. and H. Behrawan, 2008. Drought risk assessment in the western part of Bangladesh. Natural Hazards, 46: 391-413. DOI: 10.1007/s11069-007-9191-5

United Kingdom, 2008. The National Security Strategy of the United Kingdom: Security in an interdependent world. 1st Edn., The Stationery Office, Norwich, ISBN: 9780101729123, pp: 61.

UNDP, 1994. New Dimensions Of Human Security. Human Development Report 1994. United Nations Development http://hdr.undp.org/en/reports/global/hdr1994/

United Nations Development Program, 2008. Fighting Climate Change. Human Development Report 2007, 5th Edn., Palgrave Macmillan, New York, ISBN-10: 0230547044, pp: 384.

UNEP, 2005. After the tsunami: Rapid environmental assessment. 1st Edn., UNEP, Geneva, ISBN-10: 9280725653, pp: 140.

Walker, N.J. and R.E. Schulze, 2008. Climate change impacts on agro-ecosystem sustainability across three climate regions in the maize belt of South Africa. Agric. Econ. Environ., 124: 114-124. DOI: 10.1016/j.agee.2007.09.001

Wamer, W., 2010. Global environmental change and migration: Governance challenges. Global. Environ. Change, 20: 402-413. DOI:10.1016/J.GLOENVCHA.2009.12.001

Warmer, K., M. Hamza, A. Oliver-Smith, F. Renaud and A. Julca, 2010. Climate change, environmental degradation and migration. Nat. Haz., 55: 689715. DOI: $10.1007 /$ s11069-009-9419-7

Washington et al., 2006. African climate change: Taking the shorter route. Bull. Am. Meteorol. Soc., 87: 1355-1366. DOI: 10.1175/BAMS-87-10-1355

Watson, R.T. and D.L. Albritton, 2001. Climate change 2001: Synthesis report. Cambridge University Press. Cambridge, ISBN: 0521807700, pp: 397. 